\title{
Gastrointestinal Parasites Found in Domesticated Animals Introduced Into the Neo-Tropics (New World Tropics)
}

\author{
Kegan Romelle Jones* and Gary Wayne Garcia \\ Department of Food Production, The University of the West Indies, St Augustine, Trinidad and Tobago
}

Received: 恝 April 20, 2018; Published: 眥 May 04, 2018

*Corresponding author: Kegan Romelle Jones, Faculty of Food and Agriculture, Department of Food Production, The University of the West Indies, St Augustine, Trinidad and Tobago

\begin{abstract}
This paper is the first part of a three (3) part series of reviews that serves to shed light on the parasites which inhabit the gastrointestinal tract of domestic animals imported into the New World tropics (Neo-tropics), the domesticated Neo-tropical animals and the non-domesticated Neo-tropical animals (wildlife). This first review has focused on the domesticated animals introduced into the new world tropics (Neo-tropics) which were brought by the early European settlers four to five hundred years ago. These introduced Old World domesticated animal species were cattle (Bos taurus, B. indicus), sheep (Ovis aries), goat (Capra hircus), pigs (Sus scrofa), horses (Equus caballus) and chicken (Gallus domestiucus). The references used in this review were gathered and synthesized to give a clear breakdown of gastrointestinal parasites of Old World Domesticated animals. The references spanned sixty five (65) years, the earliest reference cited was in 1953 and the most recent was 2018. Most classes of gastrointestinal parasites were reviewed and tabulated by species; they were trematodes, nematodes, cestodes and coccidian. Gastrointestinal parasites which have been reported in domestic livestock species, have negatively affected the health and performances of the animals. The drugs used have been tabulated across animal species.
\end{abstract}

Keywords: Old World domesticated animals; Gastrointestinal parasites; Anthelmintic; Trematodes; cestodes; Nematodes

\section{Introduction}

In the $16^{\text {th }}$ century Spanish colonist brought animals from the Old World to the New World. These original animals were cattle (Bos Taurus, B. indicus), sheep (Ovis aries), goats (Capra hircus), pigs (Sus scrofa), horses (Equus caballus) and chicken (Gallus domestiucus) and they had to adapt to the new world conditions Reitz [1]. The first domestic animals came from Iberia or Canary Islands to Hispaniola. In Hispaniola, the local mammals were rodents such as hutia (Capromys pilorides), quitmi, mohug and a mule dog Reitz [1]. In Cubugua and Spanish Florida deer (possibly Mazama spp.) was present as a wild ruminant that may have suggested that the native ruminant diseases could have affected the domestic ruminants that were imported. The Old World animals at these locations were reported to have performed poorly due to diseases, high humidity and local competition for food. The soils were leached, acidic, and infertile and produced forage of low nutritive value Reitz [1].
Domesticated animals reared in the French West Indies were imported on the voyages from Europe in the $16^{\text {th }}$ Century. Horses were used to penetrate the country and donkeys and mules used to carry loads over hills. In Guadeloupe, in the French west Indies, the number of Old World domestic animals in the $16^{\text {th }}$ Century were 3000 cattle, 16000 horses and mules, 4000 goats and sheep Xande [2]. This paper is part of a three part series of reviews that serves to shed light on the parasites which inhabit the gastrointestinal tract of domestic animals imported into the New World tropics (Neo-tropics), the domesticated Neo-tropical animals and the nondomesticated Neo-tropical animals (wildlife). This first review has focused on the domesticated animals introduced into the new world tropics (Neo-tropics) which were brought by the early European settlers four to five hundred years ago. This review seeks to shed light on the effect of gastrointestinal parasites on Domesticated animals that were introduced to the Neo-tropics. In particular, 
cattle, sheep, goat, pigs, horses and chicken were reviewed. The review has addressed the presence of the parasite in each segment of the gastrointestinal tract and liver.

The specific objectives of this paper are

a) To define and explain "Parsasitology".

b) To review the gastrointestinal parasites of the Old World Domestic Animals (Equines, Swine, Ruminants and Chickens).

c) To review the therapeutics and management of gastrointestinal parasites of the Old World domestic animals in the New World or Neo-tropics.

\section{What is Parasitology?}

Table 1: The effect of Parasitism on Domesticated Animals Soulsby (3); Krull (4); Lapage (5).

\begin{tabular}{|c|c|}
\hline $\begin{array}{l}\text { Effects of Parasitism on } \\
\text { Domesticated Animals }\end{array}$ & Examples (Parasites) \\
\hline $\begin{array}{l}\text { Mechanical obstruction or } \\
\text { pressure }\end{array}$ & Toxocara canis \\
\hline $\begin{array}{l}\text { Deeding on tissue or fluid (blood } \\
\text { or lymph) of the host }\end{array}$ & Haemonchus contortus \\
\hline Destruction of tissue of the host & Rhipichephalis spp. \\
\hline $\begin{array}{l}\text { Absorbing food intended for the } \\
\text { host }\end{array}$ & Taenia solium \\
\hline $\begin{array}{l}\text { Stimulating the growth of nodules } \\
\text { and tumours in the }\end{array}$ & Spirocerca lupi \\
\hline \multicolumn{2}{|l|}{ host } \\
\hline $\begin{array}{c}\text { Sucking of blood or lymph from } \\
\text { the host }\end{array}$ & Ctenocephalis felis \\
\hline Irritation of the host & Amblyomma spp. \\
\hline $\begin{array}{l}\text { Producing traumatic lesions } \\
\text { through which secondary }\end{array}$ & Ostertagia ostertagi \\
\hline \multicolumn{2}{|l|}{ infection can occur. } \\
\hline $\begin{array}{l}\text { Transmitting a causal agent of } \\
\text { infectious disease }\end{array}$ & Amblyomma spp. \\
\hline $\begin{array}{l}\text { Secreting toxins or harmful } \\
\text { substances that destroy } \\
\text { tissues or organs. }\end{array}$ & Ctenocephalis felis \\
\hline
\end{tabular}

Parasitology is the study of the phenomenon of parasitism. Animal association can be broken down into (1) parasitism, (2) commensalism, (3) symbiosis and (4) mutualism. Parasitism implied a harmful association between the parasites living at the expense of the host Soulsby [3]. Krull [4] stated that a parasitic organism is one which lives on or in a host at the host's expense. Lapage [5] also stated that a parasite was an animal which lived within another animal which was called a host and the parasite gained benefits from its host and the parasite also inflicted harm to the host. There are many species of parasites, which are relatively harmless. There are many forms which have been reported to produce pathological changes which may lead to severe illness or death of the host Soulsby [3]. Lapage [5] was in agreement with Soulsby [3] and stated that host and parasite may slowly develop mutual tolerance of each other and live together with minimal effects to each other. When this did occur the host was considered to be a carrier (Table 1).

Commensalism was suggested to be where one organism benefits nutritionally from another, without at the same time harming the benefactor Soulsby [3]. In symbiosis, the original implication was that of living together between dissimilar organisms with both organisms obtaining a benefit from this relationship Soulsby [3]. Mutualism has been seen to be essentially symbiosis and the use of the term emphasises the mutual benefit derived by members of the association Soulsby [3]. An intermediate host is an organism that alternates with the definitive hosts harbours larvae or immature stages of the parasite. The definitive host is the organism that normally the sexual stages of the parasites $[4,5]$.

\section{Conclusions on "What is parasitology"}

The writings of Lapage [5], Krull [4] and Soulsby [3] have been found to be in agreement with each other on what is a parasite. In summary, a parasite is an organism that lives in its host, is metabolically depend on the host for its survival and negatively affects the host's health and performance either clinically or sub-clinically. The literature has also suggested that animal associations can be broken down into four relationships parasitism, commensalism, symbiosis and mutualism.

\section{Gastrointestinal parasites of Equine}

\section{a. Stomach}

The stomach hair worm Tricho strongylus axei was noted to have a direct life cycle and was widespread in many countries MSDAGVET [6], Krull [4], Dua [7]. The adults were found in the lumen of stomach gland and in the small intestines. These parasites are important contributing to the burden of mixed worm species infection. Parasites may have caused catarrhal gastritis that resulted in severe weight loss Dua [7]. The stomach hairworm irritated and eroded villi of the gut, damaged lymph vessels and blood vessels. Blood was lost into the gut causing melena, diarrhoea, anaemia, oedema and rapid loss of condition MSDAGVET [6], Krull [7]. Krull [7] assumed that the horse becomes infected through its association with ruminants.

Habronema muscae, H. microstoma and Draschia megastoma were found in the stomach of horses. Habronema muscae and $H$. microstma occured in the mucosal layer under the mucus while $D$. megastoma was found in tumours of the stomach wall MSDAGVET [6]; Krull [4]; Dua [7] (Table 1). These parasites have been observed to have indirect life cycles and were present in horses worldwide. The larvae or eggs released by the adult worm were ingested by the housefly (Musca) or the stablefly (Stomoxy) maggots which developed in manure. The maturation of the maggot to the adult fly allowed the larvae to develop into the infective third stage. Third stage infective larvae were deposited on wounds, lips and nostrils of the horse as the fly feeds. Krull [4] noted that the pre- 
patent period of Habronema was unknown. If licked and swallowed by host larvae matured in the stomach but if they remained in the wound deposited they didn't complete their development and remained circumscribed to the area of the wound which caused cutaneous habronemiasis.

Another method of infection was by the ingestion of flies with feed and water Krull [4]; MSDAGVET [6]; Dua [7]. Cutaneous habronemiasis was also called summer sores and occurred on the fetlock, side if neck, mouth, medial canthus of the eye, hock and knees of horses Krull [4]. Draschia megastoma promoted the formation of tumour like growths on the stomach wall which may have ruptured and occasionally which caused blockage of the passage of food from the stomach. Larvae deposited in the wound migrated and fed which extended and prevented healing. Mild digestive disorders may have resulted from gastric habronemiasis MSDAGVET [6]; Dua [7].

\section{b. Small intestine}

The horse roundworm Parascaris equorum was observed to be common throughout the world and was highly significant in foals less than six months of age. Within the egg the second stage larvae develop on pastures within 10 days to 6 weeks MSDAGVET [6]; Krull [4]. When the eggs were swallowed the larvae hatched and penetrated the intestines and were carried by the circulatory system to the lungs and liver. Migration then occurs up the trachea where they were coughed and swallowed and mature in the small intestines Dua [7]. Clinical signs have been reported in foals less than 6 months of age. Large numbers of larvae broke into the lungs which caused haemorrhage which was also accompanied by severe enteritis Dua [7]; Krull [4].

Fouls may cough and have a fever when immature larvae were present in lungs. Enteritis resulted in alternated constipation and foul-smelling diarrhoea. Mature horses rarely showed clinical signs as previously infected horses confer good resistance MSDAGVET [6]; Krull [7]. The equine intestinal threadworm Strongyloides wersteri affected horses worldwide with a predilection site for the small intestines. The only pathogenic form is a parthenogenic female Dua [7]; MSDAVET [6]. Infection occurred through ingestion of larvae or skin penetration, it involved larvae migrating to the lung and once present in the lungs they then migrated up the trachea to be swallowed MSDAVET [6].

Dua [7] stated that mares often harbour the larval stages in their tissue and they were activated in parturition to move to mammary tissue where they infected foals via milk. The mature adults were found in the small intestine, females then layed eggs that required no fertilization to develop MSDAVET [6]. These eggs were passed in faeces and then hatched to yield first stage larvae, which developed in the manner described as typical roundworms to become infective third stage larvae. This was considered as a homogenic life cycle. A homogenic life cycle involved a host and allows for rapid increase in adult threadworm population when conditions outside the hosts were unsuitable for larval development.
However, the adult threadworm in the intestine may have also layed eggs that develop into a different kind of larvae. If environmental conditions can provide necessary levels of warmth and humidity, these larvae would undergo a series of moults on the pasture to develop into the adult worm which can live outside the host. The host could have ingested male and females of this type, mate and lay eggs that eventually yielded infective third stage larvae. The type of free ranging life cycle was termed heterogenic and requires warmth and humidity Dua [7]; MSDAVET [6].

This parasite was of major importance to foals where migrating Strongyloides larvae migrated through the lungs and caused severe haemorrhage and respiratory distress. Skin penetration may have resulted in dermatitis and adult worms may have caused erosion and sloughing of the intestinal mucosa which severe interfered with digestion MSDAGVET [6]. Krull [7] found that S. westeri produced diarrhoea and emaciation in foals and has been speculated that problematic skin ailments occurred because of cutaneous penetration of infective larvae. Anoplocephala magna, A.perfoliata are the tapeworms that were found in horses. The life cycle was indirect requiring an oribatid mite as the intermediate host.

Infection occurred when a horse ate an infected mite. The parasites were found worldwide and adults were located in the small intestines and occasionally in the large intestines and caecum. Mild infection caused no clinical signs but in large numbers they caused irritation producing haemorrhage or ulcerative enteritis. Fatal intestinal blockage could have occurred at the ileocecal junction when, A. perfoliata clustered at this point of the large intestines MSDAGVET [6]. Coccidiosis in horses was caused primarily by Eimeria leukartii which caused massive intestinal haemorrhage in foals and young horses. It occurred worldwide and infected the host via ingestion of sporulated oocyst. Foals were suspected of sudden death due to this parasite and the parasite damaged the cells of the intestinal mucosa Dua [7].

\section{c. Large intestine}

Large strongyles such as Strongylus vulgaris, S.edquinus, S. edentates and Tridontophorus spp. were observed as stout bodied round worms. Adults are located in the large intestines and caecum, the eggs developed into infective third stage larvae on pasture Dua [7]; MSDAGVET [6]. When ingested third stage larvae dropped their protective sheath in the small intestines. Strongylus vulgaris was the most important large strongyle because it is the most pathogenic. Strongylus vulgaris third stage larvae penetrated the wall of the intestinal mucosa into nearby blood vessels. The larvae wondered through arteries before reaching the anterior mesenteric artery. After moulting to immature adults $S$. vulgaris returned via the arteries to the large intestine and burrowed through into the lumen Dua [7]; MSDAGVET [6].

S. equinus burrowed into the submucosa to moult, subsequent to that these parasites migrated to the liver where they wonder for 6-7 weeks. They then emerged from the liver and moulted to immature adults in various abdominal organs, then returned to 
the large intestines. S. Edentatus larvae penetrated the intestine and travelled to the liver via the portal vein where moulting occurred. Larvae then wandered the peritoneum causing nodules. The strongyle larvae formed nodules in the gut wall which they ruptured to enter the lumen of the colon MSDAGVET [6]. S. vulgaris larvae caused roughening of arterial walls providing sites for clotting MSDAGVET [6]. These clots break off and caused infarction to various parts of the body. Weakening of the blood vessels may have caused aneurysms (verminous arteritis) which could have ruptured which lead to death. Adults fed on mucosa and capillaries causing intestinal damage, anaemia, fluid loss into the intestines and blood protein loss Dua [7]; MSDAGVET [6]. Intestinal damage caused diarrhoea, fever, oedema, anaemia, anorexia, depression, weight loss and dehydration. S. equinus and $S$. edantatus caused liver damage and peritonitis MSDAGVET [6].

Craterostomum spp, Oesophagodontus spp, Gyalcephalus spp and Cyathostoma spp were referred to as small stongyles MSDAVET [6]. Dua [7] stated that Triodontophorus spp. belonged to the small strongyle group of nematodes. They have a direct life cycle, were seen in horses throughout the world and the large intestine and caecum were the sites of predilection. Small stronyles caused considerable economic losses and severe disease. Damaged was caused by the adult worms in the large intestines however larvae in gut walls may also have sucked blood. These worms were observed as plug feeders and removed intestinal mucosa and blood. Clinical signs included diarrhoea, anorexia, colic and weight loss MSDAGVET [6]; Dua [7]. In heavily infected animals there was disruption in digestive and absorptive function which resulted in catarrhal enteritis in the large intestines Dua [7].

Oxyuris equi also known as equine pinworm was observed to be common in horses throughout the world and adult worms were found in the large intestine and rectum MSDAGVET [6]. Dua [7] stated that these worms were of little significance in the intestine and had direct life cycles. Adult female worms migrated out of the anus and layed eggs on the peri-anal skin. The eggs were covered with a sticky fluid and horses may have become infected by biting at larvae in sticky fluid. Eggs may also have dropped into feed and water and matured to infected larvae where they were ingested by the horse, the larvae when ingested penetrated the lining of the large intestines where they fed on mucosa. Ulceration, loss of condition and poor appearance can be seen due to larvae feeding on mucosa but intense itching of the rump was commonly seen due to the fluid with Oxyuris eggs which was attached to the rump of the animal MSDAGVET [6] (Table 2).

Table 2: Showing predilection sites and common names of Gastro intestinal parasites in Horses.

\begin{tabular}{|c|c|c|c|c|}
\hline Parasite & Host & Common name & Predilection site & Reference \\
\hline \multicolumn{5}{|c|}{ Nematodes } \\
\hline $\begin{array}{c}\text { Habronema } \\
\text { microstoma } \\
\text { Habronema muscae } \\
\text { Draschia megastoma }\end{array}$ & Horse & $\begin{array}{c}\text { Stomach worm of } \\
\text { horses }\end{array}$ & Stomach mucosa & $\begin{array}{c}\text { Hendrix and } \\
\text { Robinson [10] } \\
\text { Zajac and Conboy [8] }\end{array}$ \\
\hline $\begin{array}{l}\text { Trichostrongylu } \\
\text { saxei }\end{array}$ & Horse & Stomach & Stomach & $\begin{array}{c}\text { Hendrix and } \\
\text { Robinson [10] } \\
\text { Zajac and Conboy [8] }\end{array}$ \\
\hline Parascaris equorum & Horse & $\begin{array}{l}\text { Equine } \\
\text { roundworm }\end{array}$ & Small intestine & $\begin{array}{c}\text { Hendrix and } \\
\text { Robinson [10] } \\
\text { Zajac and Conboy [8] }\end{array}$ \\
\hline Cyastoma chabertia & Horse & Small Stronglyes & Colon and Caecum & Zajac and Conboy [8] \\
\hline $\begin{array}{l}\text { Strongylus vulgaris } \\
\text { Strongylus edentates } \\
\text { Strongylus equinus }\end{array}$ & Horse & $\begin{array}{c}\text { Strongyle of } \\
\text { horses } \\
\text { Blood worm } \\
\text { Large strongyles }\end{array}$ & Large intestine & $\begin{array}{c}\text { Hendrix and } \\
\text { Robinson [10] } \\
\text { Zajac and Conboy [8] }\end{array}$ \\
\hline Strongyloides westeri & Horse & $\begin{array}{c}\text { Intestinal } \\
\text { threadworm of } \\
\text { horses }\end{array}$ & Small intestine & $\begin{array}{c}\text { Hendrix and } \\
\text { Robinson [10] } \\
\text { Zajac and Conboy [8] }\end{array}$ \\
\hline Oxyuris equi & Horse & $\begin{array}{l}\text { Pinworm of } \\
\text { horses }\end{array}$ & $\begin{array}{l}\text { Caecum, Colon and } \\
\text { Rectum }\end{array}$ & $\begin{array}{c}\text { Hendrix and } \\
\text { Robinson [10] } \\
\text { Zajac and Conboy [8] }\end{array}$ \\
\hline \multicolumn{5}{|c|}{ Cestodes } \\
\hline $\begin{array}{c}\text { Anoplocephala } \\
\text { perfoliata } \\
\text { Anoplocephala } \\
\text { magna } \\
\text { Paranoplocephala } \\
\text { mamillana }\end{array}$ & Horse & $\begin{array}{l}\text { Lappeted equine } \\
\text { tapeworm } \\
\text { Equine tapeworm } \\
\text { with large scolex } \\
\text { Equine tapeworm }\end{array}$ & $\begin{array}{l}\text { Small and Large } \\
\text { intestine }\end{array}$ & $\begin{array}{c}\text { Hendrix and } \\
\text { Robinson [10] } \\
\text { Zajac and Conboy [8] }\end{array}$ \\
\hline
\end{tabular}




\begin{tabular}{|c|c|c|c|c|}
\hline \multicolumn{5}{|c|}{ Protozoans } \\
\hline Giardia assempblage & Horse & Giardia & Small intestine & $\begin{array}{c}\text { Hendrix and Robinson [10] } \\
\text { Eimeria leuckarti }\end{array}$ \\
Horse & Coccidia & Small intestine & $\begin{array}{c}\text { Hendrix and Robinson [10] } \\
\text { Zajac and Conboy [8] }\end{array}$ \\
\hline
\end{tabular}

\section{d. Liver}

The common liver fluke Fasciola hepatica has been reported to occur in wet areas where the Lymnea snail existed. The predilection site was reported as the bile duct where adults layed eggs in the bile. The bile carried the eggs into the intestines. The eggs left the host in faeces where the immature fluke (miracidium) penetrated a snail. Multiplication occurred in the snail and the cercariae left the snail to be insisted on the blades of grasses. Definitive host was infected when they ingested encysted metacercariae on grasses. The parasites then penetrated the gut and passed over the liver where they migrated to the bile ducts. Migration of flukes through the liver damaged the tissue which caused scar tissue to develop which impaired the function of the liver in production of albumin. Flukes also ingested blood directly causing anaemia and decreased growth rate MSDAGVET [6] (Table 2).

\section{e. Conclusions on the gastrointestinal parasites in}

\section{Equines}

Parasites present in the digestive system of the horse caused a wide variety of clinical signs which included diarrhoea, anemia, melena, peri-arnal irritation. Small strongyles were extremely pathogenic to horses and caused damage to digestive and circulatory system. The migration of these parasites caused damage to several organs before returning to its predilection site. These parasites can have direct or indirect life cycles. The indirect life cycles required intermediate host such as Lymea spp. (snail) or mite.

\section{Gastrointestinal parasites of Swine}

\section{a. Oesophagus}

Gongylonema ransomi was observed as the gullet worm (oesophageal worm) of pigs. This parasite was observed as causing of great economic losses in swine. It affected pigs worldwide where the worms were found embedded in the tongue of the animal. Consequently there was disposal of swine tongues which were found at abattoirs when lesions were found. The life cycle was indirect and required dung beetles (Aphodius spp.) and cockroaches (Blattella germanica) for completion of the cycle. The definitive host became infected by consumption of parasitized intermediate host. The migratory path which was taken by the parasite to reach the oesophagus in domestic animals was unknown Krull [4].

\section{b. Stomach}

Physocehphalus sexalatus was reported as the thick stomach worm of pigs Krull [4]; Dua [7]; Zajac and Conboy [8]. Krull [4] noted that these parasites have worldwide distribution but seem to be absent from the British Isles. Dua [4] is in disagreement with Krull [7] and stated that the occurrence of P. sexulatus was seen worldwide. The life cycle was indirect and the coprophagic beetle was reported as the intermediate host. When egg containing larvae were eaten by host other than the coprophagic beetle the larvae encysts in tissue Dua [7]; Krull [4]. These paratenic hosts when eaten by the pig (final host) the larvae become excysted and made their way to the stomach where they reached maturity. The prepatent period was approximately 30 days. These worms were blood sucking and in light infection no clinical signs can be seen. Heavily infected animals showed anorexia, excessive thirst and restlessness Krull [4]. Dua [7] stated that clinical signs such as

those mentioned by Krull [4] were only seen when there was large numbers of worms present or if there was a reduction in body condition due to poor nutrition.

Hyostrongylus rubidus was also named the red stomach worm of pigs Krull [4]; Dua [7]. The worm had worldwide distribution and was found in the stomach. Krull [4] stated that the life cycle was direct, the eggs hatched and larvae grew and underwent a partial moult. Within 6 days the infective third stage larva was developed and hogs become infected by eating contaminated feed or rooting. In contrast Dua [7] stated that $H$. rubidus has an indirect life cycle with the intermediate host being a coprophagic beetle and pigs became infected by ingestion of the intermediate host. The pre-parent period is 25 days and clinical signs were seen as diarrhoea in young pigs and constipation in old sows. Anaemia, emaciation, haemorrhages were common clinical signs seen. In the stomach deep ulcerations may have perforated and caused death by peritonitis Krull [4]; Dua [7] (Table 3).

Table 3: Predilection sites and common names of gastrointestinal parasites in Pigs.

\begin{tabular}{|c|c|c|c|c|}
\hline Parasite & Host & Common names & Predilection site & Reference \\
\hline \multicolumn{5}{|c|}{ Nematodes } \\
\hline $\begin{array}{c}\text { Ascarops strongylina } \\
\text { Physochepahlus } \\
\text { sexalatus }\end{array}$ & Pigs & Stomach worm of pig & Stomach & $\begin{array}{c}\text { Zajac and Conboy [8] } \\
\text { Hendrix and Robinson [10] }\end{array}$ \\
\hline Hystrongylus rubidus & Pigs & Red Stomach worm & Stomach & $\begin{array}{c}\text { Hendrix and Robinson [10] } \\
\text { Zajac and Conboy [8] } \\
\text { Taylor [43] }\end{array}$ \\
\hline
\end{tabular}




\begin{tabular}{|c|c|c|c|c|}
\hline Trichostrongylus axei & Pigs & Stomach worm of pig & Stomach & Hendrix and Robinson [10] \\
\hline $\begin{array}{l}\text { Macracanthohynchus } \\
\text { hirudinaceaus }\end{array}$ & Pigs & $\begin{array}{c}\text { Thorny-headed worm of } \\
\text { swine }\end{array}$ & Small intestine & Zajac and Conboy [8] \\
\hline Ascaris suum & Pigs & $\begin{array}{l}\text { Large intestinal round } \\
\text { worm of pigs }\end{array}$ & Small intestine & $\begin{array}{l}\text { Hendrix and Robinson [10] } \\
\text { Zajac and Conboy [8] }\end{array}$ \\
\hline Strongyloides ransomi & Pigs & $\begin{array}{l}\text { Intestinal threadworm of } \\
\text { pigs }\end{array}$ & Large intestine & $\begin{array}{l}\text { Hendrix and Robinson } \\
(2017,69)[10]\end{array}$ \\
\hline $\begin{array}{c}\text { Oeosophagostomum } \\
\text { dentatum }\end{array}$ & Pigs & Nodular worm of pigs & Caecum and colon & $\begin{array}{c}\text { Hendrix and Robinson [10] } \\
\text { Zajac and Conboy [8] Taylor } \\
{[43]} \\
\end{array}$ \\
\hline Trichuris suis & Pigs & Whipworm & Caecum and colon & $\begin{array}{c}\text { Hendrix and Robinson [10], } \\
\text { Zajac and Conboy [8] }\end{array}$ \\
\hline Trichnella spirallis & Pigs & Trichina worm & Small intestine & Hendrix and Robinson [10] \\
\hline \multicolumn{5}{|c|}{ Protozoan } \\
\hline Balantidium coli & Pigs & Balantidium & Large intestine & $\begin{array}{l}\text { Hendrix and Robinson [10], } \\
\text { Zajac and Conboy [8] }\end{array}$ \\
\hline Cystoisospora suis & Pigs & Coccida & Small intestine & Hendrix and Robinson [10] \\
\hline Cryptosporidium spp. & Pigs & Cryptosporidium & Small intestine & Hendrix and Robinson [10] \\
\hline $\begin{array}{l}\text { Eimeria spp. } \\
\text { Isospora suis }\end{array}$ & Pigs & Coccidia & Intestinal tract & Zajac and Conboy [8] \\
\hline
\end{tabular}

\section{c. Small Intestines}

Ascaris suum, the large intestinal roundworm found in pigs. A. suum can migrate to other areas of the gastrointestinal tract (bile duct, stomach, large intestine, gall bladder). The life cycle was observed to be direct and the eggs have to undergo development to become infective Krull [4]; Dua [7]. The develop larvae does not hatch from the egg but undergoes a moult, host was infected by ingestion of the egg contaminated feed, water, scavenger animal which have ingested eggs and piglets are infected by contaminated udders Krull [4].The egg hatched in small intestine of definitive host and larva must undergo extra-intestinal to the lungs and liver via blood vessels before maturing and returning to the intestines when the mature larva was coughed and then swallowed. A.suum produces serious respiratory, digestive and hepatic damage due to its larval migration Krull [4]; Dua [7].

There was a pre-patent period of 75 days and clinical signs were seen due to the migrations of the immature stages and the adult worms. Many of the livers of infected pigs must be condemned at abattoirs due to the immature larvae present Krull [4]. Respiratory signs included coughing, fever and even death. In the digestive tract they caused irritation, occlusion of bile ducts and intestines. A.suum affected the pig industry greatest by the stunted growth, wasted feed, unthriftness and condemnation of carcasses Krull [4]. Dua [7] stated that the main effect of the adult worms were reduction in grow rate of young pigs but in heavily infected animals abdominal breathing can be seen due to pulmonary oedema and consolidation caused by immature larvae.

Strongyloides ransomi, hair-like worm usually found in the small intestines of pigs worldwide. The life cycle was similar to other Strongyloides spp. in which the worms have a parasitic state and a free living state. The adult females were considered to be parasitic and were found in the wall of the small intestine. Transmission occurred commonly through colostrum to affect piglets. In light infection no clinical signs were seen but under heavy infection scouring can be seen Dua [7]. Diarrhoea seen in piglets as young as ten days and severe infections can be fatal Zajac and Conboy [8]. Coccidiosis was a serious disease of pigs causing destruction of intestinal mucosa by invasion. Species which were highly pathogenic include Eimeriade bliecki, E. neodebliecki, E. scabra, E. spinosa and Isospora suis. E. spinose.

They had been seen in pigs less than three month of age causing diarrhoea while pigs between five and fifteen days were usually affected by $I$. suis. It affected swine worldwide and transmission occurred via ingestion of infective oocyst. Older animals were usually resistant to clinical disease and were sources of infection to young, susceptible animals. Oocyst of Eimeria and Isospora when passed in faeces are unsporulated. Under favourable conditions oocyst sporulated and become infective. During sporulation the development of sporozoites can be seen in the sporocyst. The Eimeria species had four sporocysts each containing two sporozoites while Isospora have two sporocysts each containing four sporozoites. When infective oocyst was ingested they encysted on the small intestine and sporzoites contained within were liberated.

Asexual reproduction took place producing merozoites and the liberated merozoite affected new cells. It is the merozoites that caused destruction of intestinal cells that can lead to death of the host. Some merozoites entered host cell and transformed into gametocytes and gametocytes transform into gametes. When gametes fused a zygote was formed which develops into an oocyst. The oocyst then escaped from the host cell and was passed in faeces. 
Clinical signs of cocciodiosis were watery or greasy diarrhoea. In piglets the small intestines was flaccid but fibronecrotic enteritis can be seen Dua [7] (Table 3).

\section{d. Large intestines}

Macracanthorhyncus hirudinaceaus are the thorny headed worm of pigs. Adults were found in the large intestines and pigs all over the world were affected. The life cycle was indirect with various beetles serving as intermediate host. The site of attachment may have a necrotic centre surrounded by inflammation. There is no specific clinical sign but peritonitis and death may be seen if intestinal wall was perforated Dua [7]. Trichuris suis commonly referred to as the whip worm of swine. It is distributed worldwide with adult worms being found in the caecum and large intestines. The life cycle is direct and infection occurs via infection of embryonated ova. These parasites had been found in the intestinal tract of human on occasion. Most cases in animals were asymptomatic but heavy infection could have caused diarrhoea and unthriftiness Dua [7]. Commonly found in pigs and may have caused severe diarrhoea and dehydration. In severe cases bloody diarrhoea may have be seen Zajac and Conboy [8] (Table 3).

\section{e. Conclusions of gastrointestinal parasites of swine}

Parasites of the pigs which were found in the digestive tracks caused economic losses in the following ways

i. Larval migration causing of damaged organs and condemning of affected organ at the abattoir.

ii. Decrease growth rate of infected pigs.

iii. Death of animals that succumb to parasitic disease.

Strongyloides spp. has two states, a parasitic and non-parasitic state with the females being parasitic and were found in the final host. Migration of larvae throughout the body can cause digestive and respiratory signs. Adult cestodes were absent in the digestive tract of pigs.

\section{Ruminants}

\section{a. Rumen/ Reticulum}

Paramphistomes were flukes which were found in the reticulum of cattle and to a lesser extent sheep. The adults don't cause ill effects but the immature forms which reside in the lining of the small intestine causes enteritis. The life history is similar to the liver fluke where the fresh water snail was observed as the intermediate host Belschner [9].

\section{b. Abomasum}

Haemonchus contortus was also called the large stomach worm of ruminants. While Belschner [9] stated that the barber pole worm was called Haemonchus placei .Dua [7] showed that Haemonchus placei was found in cattle while Haemonchus contortus was found in sheep and goat. Cross transmission of Haemonchus between sheep and cattle can occur with sheep being more susceptible. This worm has a worldwide distribution and adults were found in the abomasum. Sheep and goat were usually affected but may also infect ox, goat, moose, deer, antelope, bison and musk Krull [7]. In contrast Dua [7] stated that Haemonchus occurs in tropical and sub-tropical condition. The life cycle was recorded as direct; eggs are produced by females which were shed in faeces. The larva completed its development in faeces or in the ground. The larva then moulted twice to become third stage infective larva in approximately four days. Infective larvae were active and climbed unto grass to be ingested by the definitive host.

The third stage larva then became exsheathed in the stomach; entered the gastric pits and mucosa. Here it feds on blood, moulted and then returned to the lumen where the last moult occurs Krull [4]; Belschner [9]; Dua [7]. Belschner [9] stated that the pre-patent period was between twenty five (25) to twenty eight (28) days. In contrast Dua [7] found that the pre-patent period was between two to three week (14-21 days). Lesions were produced by the immature larvae and adults that attacked the mucosa of the abomasum. The worm's mouth part possessed a lancet which was used to secure blood and elicit bleeding. Animal infected are emaciated, oedema, have rough hair coat, have pale mucus membranes and are diarrheic Krull [4]; Dua [7]. Young cattle were usually heavily infected and can cause death due to the blood loss that the parasite caused Belschner [9].

Ostertagia ostertagi was observed in the stomach is also known as the brown stomach worm primarily found in cattle Krull [4]; Dua [7]. 0 . circumcincta and 0 . trifurcate is found in sheep and goat Dua [7]. It has a worldwide distribution and adults were found in the abomasum (true stomach). These parasites were found in bison, antelope and sheep but as occasional host. These parasites occurred worldwide and have a pre-patent period of 22 days Krull [4]. Breschner [9] grouped Ostertagia ostertagi, Trichostrongylus axei and Cooperia spp. as short hair worms which was found in the fourth stomach. In young cattle it caused stunted growth and scouring. Krull [4] stated that affected animals have stomach walls which were elevated, inflamed, haemorrhagic and oedematic. Symptoms seen were emaciation, pale mucous membranes, rough hair coat and diarrhoea. Deaths were seen in severe cases and identification of the parasite cannot be done by eggs Dua [7]; Krull [4].

Krull [4] stated that Trichostrongylus axei and T. columbriformis were found in the abomasum and small intestines of sheep, goat and cattle. Dua [7] stated that Trichostongylus axei was found in the abomasum of ruminants and the stomach of horses and pigs. These parasites are extremely pathogenic and were not very host specific and caused disease to domesticated, wild and sometimes man. The life cycle was direct; eggs were discharged in faeces and moulted twice to become infective third stage larva. The infective stage larvae migrated from faeces and attach to grasses. Infection 
occurred when third stage larvae was ingested by definite host. The infective larvae when ingested entered the submucosa and moult before returning to the lumen. The pre-patent period may have ranged from 15-23 days Krull [4].

Clinical signs in sheep and goats were seen when the number of worms ranged from 2,000 to 10,000 per animal. Krull [4] assumed that the pathogenic effect was due to the toxins it produced but not the blood sucking. Young lambs and kids were usually affected showing acute signs of weight loss and reduced appetite. Mixed infection with Nematodirus spp. intensifies the pathogenic potential. In sheep it caused reduced gains, interference with wool production, and depression in protein digestibility and depression in calcium and phosphorus utilization. Phenothiazine was used in the treatment of twisted stomach worm and lesser stomach worm which inhabit the abomasum. Proper sanitation can control the transmission of this disease Haberman [11].

\section{c. Small intestine}

Trichostrongylus columbiformis and Trichostongylus vitrinus were found in the small intestines of ruminants worldwide. $T$. vitrinus was found mostly in sheep and goat and was observed as having a pre-patent period of 18-21 days. The life cycle was direct and larvae burrowed superficially in the crypts of the mucosa. Clinical signs were anorexia, persistent diarrhoea and weight loss Dua [7]. Cooperiosis was reported as a parasitic disease of ruminants caused by the parasite Cooperia. C. punctate, $C$. pectinate and $C$. onchophora parasitized cattle. C. surnabada parasitized cattle and sheep while $C$. curticeii affected sheep and goat. These worms don't suck blood but caused profuse diarrhoea, anoexia and emaciation. The life cycle was direct with a pre-patent period of 1215 days Dua [7].

Nematodirus helvetianus affected the small intestine of cattle while $N$. battus affects sheep worldwide. The life cycle was reported as direct with $N$. battus more commonly seen in temperate regions; animals became infected by ingestion of third stage larvae. Clinical infection was usually seen from six week onward in dairy cattle but in sheep there was a sudden onset of unthriftiness, profuse diarrhoea, marked dehydration and death. Nematodirosis was common in confined lambs or weaned sheep with lesions of dehydration, catarrhal enteritis or acute inflammation of the small intestines Dua [7]. Belschner [9] agreed with Dua [7] and stated that Nematodirus spp. was the thin necked intestinal worm found most commonly in the small intestines. Heavy infection by the immature larval stages could have caused death in young cattle with a direct history similar to the barber's pole worm. Bunostomum phlebotomum the hookworm of cattle is fairly common in coastal areas and heavy infection was usually seen in calves. The hookworm fed on blood and tissue in the intestines; it adhered to the intestinal wall and drew blood using its mouthpart. Infection could have occurred via ingestion of infective larvae or by larvae boring through the animal's skin. The larvae migrated in the body and were carried to the lungs where they developed and were coughed up and swallowed to reach the intestine Belschner [9]; Dua [7]. Belschner [9] stated that the pre-patent period was two (2) months. Dua [7] found that the pre-patent period could have ranged from 30-56 days. Signs of infection were similar to the barber's pole worm where there was rapid loss of condition, anaemia and bottle jaw Belschner [9]; Dua [7].

Neoascaris vitulorum also known as the large roundworms of cattle were commonly found in the small intestines of calves. These parasites were found worldwide affecting cattle, caribou and Indian buffalo but were more prevalent in tropical areas. The life cycle was direct and host became infected by ingesting infective eggs. The larvae then migrated to lung and liver to mature and then returned to the small intestines as adults Krull [4]; Dua [7]. Krull 1968 [4] stated that the life cycle is similar to Ascarids seen in pigs and the pre-patent period is two and a half months (75 days). Dua [7] was in disagreement with Krull [4] stated that the pre-patent period was 3-4 weeks and transmammary infection occured in pregnant cows where larvae mobilized to be passed in milk which was fed to calves. Clinical signs were anorexia, diarrhoea, colic and a lack of endurance Krull [4]; Dua [7].

Strongyloides papulosus was observed as a slender like worm measuring $3.5-6 \mathrm{~mm}$ long. These worms were found in the small intestines of ruminants worldwide. Strongyloides have unusual life cycles in which eggs produced in faeces of host can develop into infectious larvae or free living adults. Transmission occurs by ingestion or skin penetration of larvae. Infection was usually seen in calves but clinical signs were rare but large worm burden may cause diarrhoea and loss of appetite Dua [7]. Monezia benedeni was recorded as a tapeworm that occurs in cattle found in the small intestines. The microscopic mite was observed as the intermediate host and cattle became infected by ingesting mites by grazing. Heavily infected calves had intestinal obstruction with loss of body condition Belschner [9].

In ruminant coccidiosis was observed to be of great economic importance worldwide. They were found in the small intestines but can also be found in the liver. They occurred worldwide and specific species affect sheep, goats and cattle. In cattle Eimeria zuernii and $E$. bovis were the most pathogenic. In sheep E. crandallis, E. ovinoidalis and E. ovina was seen with E. ovinoidalis being a serious pathogen of lambs. In goats E. arloingi, E. christenseni and E. ovinoidalis were seen with the later (E. christenseni and E. ovinoidalis) being highly pathogenic to kids Dua [7]; Zajac and Conboy [8]. Transmission occurred by ingestion of infected cyst. The life cycle was similar to Eimeria species found in pigs. The virulence of these organism was linked with stressors such as poor nutrition, poor sanitation, weaning, shipping, severe weather or change in feed. Young ruminants were usually susceptible to disease and having a prepatent period of seventeen to twenty one days. Clinical signs included diarrhoea, fever, tenesmus, ill- thrift, inappetence and death Dua [7]. 


\section{d. Large intestine}

Oesophagustomum radiatum also known as the nodular worm was found in the large intestine Belschner [9]. O. radiatum were found in cattle and buffaloes while 0 . columianum was found in sheep and goats Dua [7]. The life cycle was recorded as direct and consisted of eggs being passed in faeces and larvae development occurring in optimum conditions. The infective larvae were then ingested by the host where it burrowed into the bowel wall and formed nodules on the intestines Dua [7]; Belschner [9]. The larvae left the nodule upon maturity and were present in the intestinal lumen. The pre-patent period is six weeks and clinical signs were similar to other endoparasites and entailed loss of condition, soft dropping containing mucus and haematochezia Belschner [9]; Dua [7].

Chabertia ovina was observed as the large nematode found in the colon of ruminant. It was mainly found in sheep and goat but was occasionally seen in cattle with a worldwide distribution. The life cycle was reported as being direct and in sheep soft blood flecked faeces can be seen. Death occurred with heavy infection but clinical signs were seldom seen in cattle Dua [7]. Trichris globulosa, the whipworm found in the caecum of cattle worldwide while Trichuris ovis is found in sheep and goat. The infection was common in calves with larvae and adult causing small haemorrhages and oedema in the colon. These worms have a pre-patent period of 6-12 weeks Dua [7].

\section{e. Liver}

Fasciola hepatica was reported to be found in the bile duct of sheep, goat, ox and other ruminants (Table 4). In unusual host such as man and horse the fluke was found in the lungs and under the skin. The fluke caused fasioliasis (liver fluke disease, liver rot) especially in sheep and cattle Soulsby [3]; Belschner [9]; Dua [7]. The eggs entered the duodenum with the bile and left the host in the faeces. The rate of development for hatching of the eggs was dependent upon environmental temperatures. The miricidium penetrated actively into the snail (Lymnea spp.) and developed into the sporocyst. Each sporocyst give rise to rediae which further developed into cercariae. Cercariae escaped from snails and settled on the blades of grass just below water level. The cercariae were then swallowed by the final host with plants on which they were encysted Soulsby [3]; Belschner [9]; Dua [7].

Table 4: Predilection sites and common names of gastrointestinal parasites in Ruminants.

\begin{tabular}{|c|c|c|c|c|}
\hline Parasite & Host & Common names & Predilection site & Reference \\
\hline \multicolumn{5}{|c|}{ Nematodes } \\
\hline Gongylonemapulchrum & $\begin{array}{l}\text { Sheep, goats } \\
\text { and cattle }\end{array}$ & $\begin{array}{l}\text { Oesophageal } \\
\text { worms of } \\
\text { ruminants }\end{array}$ & $\begin{array}{l}\text { Submucosa and } \\
\text { mucosa of the } \\
\text { oesophagus }\end{array}$ & Hendrix and Robinson [10] \\
\hline $\begin{array}{c}\text { Bunustomum spp. } \\
\text { Chabertia spp. } \\
\text { Cooperia spp. } \\
\text { Haemonchus spp. } \\
\text { Oesophagostomum spp. } \\
\text { Ostertagiaspp. } \\
\text { Trichostrongylus spp. } \\
\text { Nematodirus spp. } \\
\text { Marshallagia spp. }\end{array}$ & $\begin{array}{l}\text { Cattle, sheep } \\
\text { and goats } \\
\text { Ruminant and } \\
\text { camelid }\end{array}$ & $\begin{array}{c}\text { Brown stomach } \\
\text { worm } \\
\text { Barber pole } \\
\text { Worm } \\
\text { Hookworm } \\
\text { Threaded-necked } \\
\text { worm } \\
\text { Nodular worm } \\
\text { Strongyles } \\
\text { Trichostrongyle } \\
\text { of ruminants }\end{array}$ & $\begin{array}{l}\text { Abomasum, small } \\
\text { intestine and large } \\
\text { intestine }\end{array}$ & $\begin{array}{c}\text { Hendrix and Robinson [10] } \\
\text { Zajac and Conboy [8] }\end{array}$ \\
\hline Strongyloidespappulosus & Cattle & $\begin{array}{l}\text { Bovine intestinal } \\
\text { threadworm }\end{array}$ & Small intestine & $\begin{array}{c}\text { Hendrix and } \\
\text { Robinson [10] } \\
\text { Zajac and Conboy [8] }\end{array}$ \\
\hline $\begin{array}{c}\text { Aonchotheca } \\
\text { (Capillaria)spp. } \\
\text { A. bovis } \\
\text { A.longipes }\end{array}$ & $\begin{array}{l}\text { Ruminants } \\
\text { and Camelids }\end{array}$ & Capillaria & Small intestines & Zajac and Conboy [8] \\
\hline $\begin{array}{c}\text { Toxocara (Neoascaris) } \\
\text { vitulorum }\end{array}$ & $\begin{array}{l}\text { Cattle and } \\
\text { Bison }\end{array}$ & Roundworm & Small intestine & Zajac and Conboy [8] \\
\hline $\begin{array}{c}\text { Trichuris spp. } \\
\text { T.ovis } \\
\text { T.discolor }\end{array}$ & $\begin{array}{l}\text { Cattle, sheep } \\
\text { and goats }\end{array}$ & Whipworms & Caecum and colon & $\begin{array}{c}\text { Hendrix and } \\
\text { Robinson [10] } \\
\text { Zajac and Conboy [8] }\end{array}$ \\
\hline \multicolumn{5}{|c|}{ Cestodes } \\
\hline $\begin{array}{c}\text { Moniezia spp. } \\
\text { Moniezia benedini } \\
\text { Moniezia expansa }\end{array}$ & $\begin{array}{l}\text { Ruminants } \\
\text { and Camelids }\end{array}$ & $\begin{array}{l}\text { Ruminant } \\
\text { tapeworm }\end{array}$ & Small intestine & $\begin{array}{c}\text { Hendrix and } \\
\text { Robinson [10] } \\
\text { Zajac and Conboy [8] }\end{array}$ \\
\hline
\end{tabular}




\begin{tabular}{|c|c|c|c|c|}
\hline Thysanosoma actinodes & Cattle, sheep and goat & $\begin{array}{l}\text { Fringed tape worm of sheep } \\
\text { and goat }\end{array}$ & Small intestine & $\begin{array}{l}\text { Hendrix and Robinson [10] } \\
\text { Zajac and Conboy [8] }\end{array}$ \\
\hline \multicolumn{5}{|c|}{ Trematodes } \\
\hline Dicrocoelium dendriticum & Cattle, sheep, goat & Lancet fluke & Bile ducts & $\begin{array}{l}\text { Hendrix and Robinson [10] } \\
\text { Zajac and Conboy [8] }\end{array}$ \\
\hline $\begin{array}{l}\text { Paramphistomum spp. } \\
\text { Cotylophoron spp. }\end{array}$ & Cattle, sheep,goat & Rumen flukes & Reticulum and Rumen & $\begin{array}{l}\text { Hendrix and Robinson [10] } \\
\text { Zajac and Conboy [8] }\end{array}$ \\
\hline Fasciola hepatica & $\begin{array}{l}\text { Cattle, goat. Sheep and } \\
\text { camelids }\end{array}$ & Liver fluke & Bile duct & $\begin{array}{l}\text { Hendrix and Robinson [10] } \\
\text { Zajac and Conboy [8] }\end{array}$ \\
\hline \multicolumn{5}{|c|}{ Protozoan } \\
\hline Eimeria spp. & Ruminants & Coccidia of ruminants & $\begin{array}{l}\text { Caecum and colon Intestinal } \\
\text { tract }\end{array}$ & $\begin{array}{l}\text { Hendrix and Robinson [10] } \\
\text { Zajac and Conboy [8] }\end{array}$ \\
\hline \multicolumn{5}{|l|}{ Eimeria bovis } \\
\hline \multicolumn{5}{|l|}{ Eimeria zuernii } \\
\hline Cryptosporidium spp. & Cattle & Cryptosporidia & Small intestine & $\begin{array}{l}\text { Hendrix and Robinson [10] } \\
\text { Zajac and Conboy [8] }\end{array}$ \\
\hline $\begin{array}{l}\text { Cryptosporidium parvum } \\
\text { Giardia intestinalis } \\
\text { Giardia lambia } \\
\text { Giardia duodenalis } \\
\text { Giardia bovis }\end{array}$ & $\begin{array}{c}\text { Ruminants } \\
\text { Ruminants and Camelids }\end{array}$ & Gardia & Small intestine & Zajac and Conboy [8] \\
\hline
\end{tabular}

Following ingestion the metacercaria excysted in the duodenum. Within 24 hours of infection the majority of immature trematodes occurred in the abdominal cavity. They then penetrated the liver capsule and migrated through the liver parenchyma. The pathological lesions manifested depended upon the number of metacercariae ingested. No appreciable damage was done during penetration of intestinal wall or the peritoneal cavity Soulsby [3]. The principle lesions occurred in the liver parenchyma or bile duct. The disease entity can be divided into acute fascioliasis and chronic fascioliasis Soulsby [3]; Dua 2012 [7]. The acute form was usually seen in sheep and is essentially traumatic hepatitis produced by the migration of large numbers of immature trematodes.

Animals may die a few days after the development of clinical signs due to haemorrhage in the abdominal cavity caused by extensive destruction to liver parenchyma. A complication of this acute condition was "Black disease" caused by Clostridium oedematiens novyi. The bacterium invaded after hepatic damage by the parasite to anaerobic necrotic lesions Soulsby [3]; Belschner [9]; Dua [7]. Chronic fascioliasis was more common in sheep, cattle and other animals. The pathology was divided into hepatic fibrosis and hyperplastic cholangitis Soulsby [3]; Belschner [9]; Dua [7]. Migration of immature flukes in the liver parenchyma caused haemorrhage and necrosis. Healing and regeneration of these lesions caused collagen and fibrin to be deposited.

The hyperplastic cholangitis was caused by the presence on adult flukes in the bile ducts. At first the epithelium of the bile ducts became hyperplastic, both close to and distal to the site of fluke residence. Animals suffered from anaemia due to the blood sucking activity of the adult flukes. Oedema may have occurred due to the hypoproteinemia and was seen as "bottle jaw" Soulsby [3]; Belschner [9]; Dua [7]. Dicrocoelium dendriticum was found in the bile duct of ruminants Soulsby [3]. Two intermediate hosts were a snail and an ant. Two principal snail hosts were Zebrina detrita in Europe and Cionella lubrica in North America. The miricidium do not hatch out of the egg until the eggs have been swallowed by the intermediate host. They hatch in the gut of the snail, the sporocyst was then converted into cercariae and there was no redia stage. The cercariae emerged from the snail in damp and clump into a slime ball. The slime balls were eaten by ants of genus Formica Soulsby [3].

Metacercariae were produced in the abdominal cavity and some were found in the brain of the ant. Definitive host was infected by swallowing infected ants. Cercariae entered the liver via the bile duct, these flukes penetrated the fine branches of the bile duct. Despite heavy burdens which may have occurred pathological lesions were not seen. In advanced infection there was extensive cirrhosis and scarring of the liver surface and the bile duct is markedly distended with large number of flukes. In severe cases anaemia, oedema and emaciation could have been be seen but many cases showed no clinical signs Zajac and Conboy [8]; Hendrix and Robinson [10]. Control of the snails (Intermediate host) could be done by proper draining of water log pasture and the use of Hexachlorethane in environment Haberman [11]. Parker [12] stated that control was done by eliminating the intermediate host (snail) which will break the cycle (Table 4).

\section{f. Conclusions on the gastrointestinal parasites of}

\section{Ruminants}

Haemonchus spp., Ostertagia spp. and Trichostrongylus spp. caused severe damage to the abomasum of Old World Domestic Ruminant and impeded ruminant production. Nematodirus spp. affected sheep causing devastating clinical signs whereas when these parasites are found in other ruminants caused milder 
clinical signs. Subcutaneous oedema (Bottle Jaw) was reported in ruminants when large numbers of gastrointestinal parasites was present which removed protein (blood, plasma protein).

\section{Chickens}

\section{a. Oesophagus}

Mukaratirwa et al. [13] found Gonglyonema inguvicola, Skrjabinocerca spp. and Capillaria contorta in the oesophagus of chickens. Mungube et al. [14] identified Capillaria contorta and Gonglyonema ingluvicola in the oesophagus of free ranging chickens in Kenya.

\section{b. Crop}

In Nairobi Kenya Maina et al. [15], Mbeere Kenya Cheg et al. [16] and Chota et al. [17] free ranging chickens Gonglyonema ingluvicola was found in the crop. Capillaria contorta and Dispharynx nasuta was found in the crops of chickens in Zimbabwe Mukaratirwa et al. [13]. Mungube et al. [14] located Capillaria contorta in free ranging chickens in Kenya.

\section{c. Proventriculus}

Tetameres americana was found in the proventriculus of free ranging chickens Maina et al. [15]; Cheg et al. [16]; Mukaratirwa et al. [13]; Mungube et al. [14]; Chota et al. [17]. Dispharynx nasuta was also found in the proventriculus in chickens in Zimbabwe Mukaratirwa et al. [13] but was found in the trachea in chickens in Kenya Mungube et al. [14]. Dispharynx spiralis was identified in Kenya Mungube et al. [14].

\section{d. Gizzard/ Ventriculus}

In Nairobi Kenya, free ranging chickens were examined. In the gizzards Acuaena hamulosa was found Maina et al. [15]. Cheilospirura spp. was found in the gizzard of chickens in Zimbabwe Mukaratirwa et al. [13]; Mungube et al. [14].

\section{e. Small intestine}

In chickens two forms of coccidiosis were seen; chronic form and acute form. The chronic form was found in the small intestines with the causative agent reported as Eimeria tenella. There was also E. nacatrix, E. maxima, E. acervulina, E. mitis, E.praecox, E. hagoni and $E$. brunetti which also caused intestinal coccidiosis. Destruction of intestinal cells by the parasites caused diarrhoea, bloody droppings and decreased in feed intake. Sulphur based drugs such as sulfaguanadine, sulfamethazine, sulfamerazine, sulfadiazine, sulfapyrazine and sulfaquinoxaline Haberman [11] (Table 5). Coccidia were common in domestic birds and many infections were reported to be asymptomatic but where poultry was confined Eimeria spp. were important pathogens. Sexual and asexual multiplication occurred within cells of the intestinal walls Zajac and Conboy [8]. Cryptospotidiumbaileyiand C. melaegridis were found in the gastrointestinal tract and caused diarrhoea. This parasite is zoonotic Zajac and Conboy [8].

Table 5: Predilection sites and common names of Gastro intestinal parasites in Chickens.

\begin{tabular}{|c|c|c|c|c|}
\hline Parasite & Host & Common Name & Predilection site & References \\
\hline \multicolumn{5}{|c|}{ Nematodes } \\
\hline Ascaridia spp. & Birds & Ascarids of birds & Small intestine & $\begin{array}{l}\text { Hendrix and } \\
\text { Robinson [10] }\end{array}$ \\
\hline Skrjabinocerca spp. & Chickens & & Oesophagus & Makaratirwa et al. [13] \\
\hline Heterakis gallinarum & Poultry & Avian ascarids & Caeca & $\begin{array}{c}\text { Zajac and Conboy } \\
\text { [8] } \\
\text { Maina et al. [15] } \\
\text { Cheg et al. [16] } \\
\text { Makaratirwa et al. } \\
\text { [13] } \\
\text { Chota et al. [17] }\end{array}$ \\
\hline H. isolonche & Chickens & & $\begin{array}{l}\text { Caeca and Large } \\
\text { intestines }\end{array}$ & $\begin{array}{l}\text { Maina et al. [15] } \\
\text { Cheg et al. [16] }\end{array}$ \\
\hline Gonglyonema ingluvicola & Chickens & & Crop & $\begin{array}{l}\text { Maina et al. [15] } \\
\text { Cheg et al. [16] Makaratirwa } \\
\text { et al. [13] Mungube et al. } \\
\text { [14] Chota et al. [17] }\end{array}$ \\
\hline Stronguloides avium & Chickens & & Small intestines & Mungube et al. (14) \\
\hline Dispharynx spiralis & Chickens & & Proventriculs & Mungube et al. (14) \\
\hline Sublura brumpti & Chickens & & $\begin{array}{l}\text { Caecum and Large } \\
\text { intestines }\end{array}$ & $\begin{array}{c}\text { Maina et al. (15) Cheg et } \\
\text { al. (16) }\end{array}$ \\
\hline Allodapa brumpti & Chickens & & Caecum & Makaratirwa et al. [13] \\
\hline Allodapa suctoria & Chicken & & Caecum & Chota et al. [17] \\
\hline Acuenia galli & Chickens & & Ventriculus & Maina et al. [15] \\
\hline Cheilospirura hamulosa & Chickens & & Ventriculus & $\begin{array}{l}\text { Makaratirwa et al. [13] } \\
\text { Mungube et al. [14] }\end{array}$ \\
\hline
\end{tabular}




\begin{tabular}{|c|c|c|c|c|}
\hline Tetrameres americana & Chickens & & Proventriculus & $\begin{array}{c}\text { Maina et al. [15] Cheg et al. } \\
\text { [16] Makaratirwa et al.[13] } \\
\text { Mungube et al.[14] }\end{array}$ \\
\hline Ascaraidia galli & Chickens & & $\begin{array}{l}\text { Duodenum and Small } \\
\text { intestines }\end{array}$ & $\begin{array}{c}\text { Maina et al, [15] } \\
\text { Makaratirwa et al.[13] } \\
\text { Mungube et al. [14] Chota } \\
\text { et al. [17] }\end{array}$ \\
\hline Capillaria spp. & Poultry & Capillaria & $\begin{array}{l}\text { Crop and upper alimentary } \\
\text { tract }\end{array}$ & $\begin{array}{c}\text { Hendrix and Robinson [10] } \\
\text { Zajac and Conboy [8] Maina } \\
\text { et al. [15] }\end{array}$ \\
\hline Capillaria obsingata & Chickens & & Small intestines & Makaratirwa et al.[13] \\
\hline Capillaria contorta & Chickens & & Oesophagus and Crop & $\begin{array}{l}\text { Makaratirwa et al.[13] } \\
\text { Mungube et al. [14] }\end{array}$ \\
\hline Dispharynx nasuta & Chickens & & Crop and Oesophagus & Makaratirwa et al. [13] \\
\hline Trichostrongylus tenuis & Poultry & Avian Strongylids & Caeca and intestines & $\begin{array}{l}\text { Zajac and Conboy [8] } \\
\text { Makaratirwa et al. [13] }\end{array}$ \\
\hline Amidostomium anseri & Poultry & & Caeca and Intestines & Zajac and Conboy [8] \\
\hline \multicolumn{5}{|c|}{ Trematodes } \\
\hline $\begin{array}{l}\text { Echinostoma spp. } \\
\text { Echinoparyphium spp. } \\
\text { Prostogonimus spp. }\end{array}$ & Poultry & Fluke & $\begin{array}{l}\text { Various body systems } \\
\text { (intestines, respiratory, } \\
\text { reproductive) }\end{array}$ & Zajac and Conboy [9] \\
\hline \multicolumn{5}{|c|}{ Cestodes } \\
\hline $\begin{array}{c}\text { Davinea spp. } \\
\text { Choanotaenia spp. } \\
\text { Raillietina spp. } \\
\text { Hymenolepsis spp. }\end{array}$ & Poultry & Tapeworm & Small intestine & Zajac and Conboy [8] \\
\hline Davinea proglottina & Chickens & & Duodenum & $\begin{array}{c}\text { Maina et al. [15] Cheg et } \\
\text { al. [16] }\end{array}$ \\
\hline Hymenolepsis carioca & Chickens & & Small intestines & $\begin{array}{l}\text { Maina et al. [15] Cheg et al. } \\
\text { [16] Mungube et al. [14] }\end{array}$ \\
\hline Raillietina echinobothria & Chickens & & Small and Large intestines & $\begin{array}{l}\text { Maina et al. ([15] Cheg et al. } \\
\text { [16] Mungube et al. [14] }\end{array}$ \\
\hline Raillietina tetragona & Chickens & & Small and Large intestines & $\begin{array}{c}\text { Mainia et al. [15] Cheg et } \\
\text { al. [16] }\end{array}$ \\
\hline R. cesticillius & Chickens & & Large intestines & Maina et al [15] \\
\hline Choanataenia infundibulum & Chickens & & Small intestines & $\begin{array}{c}\text { Cheg et al. [16] Mungube et } \\
\text { al. [14] }\end{array}$ \\
\hline Amoebotaenia spheroids & Chickens & & Small intestines & Mungube et al. [14] \\
\hline \multicolumn{5}{|c|}{ Protozoan } \\
\hline Histomonas meleagridis & Poultry & Blackhead & Liver & $\begin{array}{l}\text { Hendrix and Robinson [10] } \\
\text { Zajac and Conboy [8] }\end{array}$ \\
\hline Trichomonas gallinae & Poultry & Trichomonas & Crop & $\begin{array}{l}\text { Hendrix and Robinson [10] } \\
\text { Zajac and Conboy [8] }\end{array}$ \\
\hline $\begin{array}{l}\text { Eimeria spp. } \\
\text { Isospora spp. }\end{array}$ & Poultry & Coccidia & Small intestine, caecum & Zajac and Conboy [8] \\
\hline $\begin{array}{l}\text { Cryptosporidium spp. } \\
\text { C. baileyi } \\
\text { C. melaegridis } \\
\end{array}$ & Poultry & Cryptosporidium & Small intestines & Zajac and Conboy [8] \\
\hline Eimeria necatrix & Chicken & & Small intestines & Mungube et al. [14] \\
\hline Eimeria tenella & Chicken & & Caecum & Mungube et al.[14] \\
\hline
\end{tabular}

In the small intestines of free ranging chickens in Nairobi Kenya parasites were observed. Endoparasites found were Ascaridia galli, Raillietina echinoborthrida, Raillietina tetragona, Davinea proglottina and Hymenolepsis carioa Maina et al. [15]. Mungube et al. [14] identified cestodes; $R$. echinobothrida,
Choanataenia infundibulum, D. proglottina and Amoebotaenia sphenoids. Nematodes identified were A. galli, Strongyloides avium, Ttrichostrongylus tenuis and coccidian Eimeria necatrix. Cheg at al. [16] found Hymenolepsis canteniana, Choanataenia infundibulum, R. echinoborthrida, Davinaea Proglottina. Mukaratirwa et al. [13] 
found Trichostrongylus tenuis and Capillaria contorta in the small intestines of free range chickens in Zimbabwe. Chota et al. [17] recorded A. gallinarum in the small intestines of scavenger chickens in Zambia.

\section{f. Caeca and Large intestines}

In the caeca and large intestines of chicken in Nairobi Kenya Heterakis gallinarum, $H$. isolonche, Subuluria brumpti and Raillietina cesticullius, R. echinobothrida were found Maina et al. [15]. In another county in Kenya (Mbeere) Heterakis spp., H.isolonche, H.gallinarum, Subulura brumpti, R. echinobothrida and R.tetagena was found Cheg et al [16]. Mukaratirwa et al. [13] found Allodapa brumpti and Heterakis gallinarum in the caecum of free range chicks in Zimbabwe. Mungube et al. [14] recorded Eimeria tenella in the cecum of free ranging chickens in Kenya. Chota et al. [17] identified Heterakis gallinarum in the ceaecum of chickens in Zambia (Table $6)$.

Table 6: Chemotherapeutic agents recommended for Treatment and Control of Coccidiosis (sourced from Dua (7).

\begin{tabular}{|c|c|c|c|}
\hline $\begin{array}{c}\text { Chemotherapeutic } \\
\text { agent }\end{array}$ & Species & Treatment & Prevention \\
\hline \multirow{2}{*}{$\begin{array}{l}\text { Sulphadimidine } \\
\text { (Sulphamethazine) }\end{array}$} & Calves & \multirow{2}{*}{$\begin{array}{l}140 \mathrm{mg} / \mathrm{kg} \mathrm{BW} \text { orally for } \\
3 \text { months }\end{array}$} & $\begin{array}{l}35 \mathrm{mg} / \mathrm{kg} \mathrm{BW} \text { for } 15 \text { days } \\
\text { in feed }\end{array}$ \\
\hline & Lambs & & 25mg/kg BW for 7 days \\
\hline \multirow{4}{*}{ Sulphaquinoxaline } & \multirow{3}{*}{ Lambs } & $0.015 \%$ concentration in & \\
\hline & & drinking water for 3-5 & \\
\hline & & days & \\
\hline & Cattle & $6 \mathrm{mg} / \mathrm{Ib} /$ day for 3-5 days & \\
\hline \multirow[b]{3}{*}{ Amprolium } & Calves & \multirow[b]{3}{*}{$\begin{array}{c}10 \mathrm{mg} / \mathrm{kg} \text { BW orally for } 5 \\
\text { days } \\
\text { Or } 65 \mathrm{mg} / \mathrm{kg} \text { once }\end{array}$} & $\begin{array}{l}5 \mathrm{mg} / \mathrm{kg} \text { BW orally for } 21 \\
\text { days }\end{array}$ \\
\hline & Lamb & & \\
\hline & Piglets & & $\begin{array}{c}\text { Amprolium (25\% feed } \\
\text { grade) at the rate of } \\
10 \mathrm{~kg} / \text { tonne of sows' feed } \\
\text { started } 1 \text { week before } \\
\text { farrowing and continued } \\
\text { until the piglets are } 3 \\
\text { wks of age has been recommended, } \\
\text { but the results are unsatisfactory }\end{array}$ \\
\hline \multirow[b]{2}{*}{ Monensin } & Calves & \multirow[b]{2}{*}{$\begin{array}{l}2 \mathrm{mg} / \mathrm{kg} \text { BW for } 20 \text { days beginning } \\
\text { on the } 13 \text { th days of experimental } \\
\text { inoculation }\end{array}$} & $\begin{array}{c}16.5 \text { or } 33 \mathrm{~g} / \text { tonne of feed for } 31 \\
\text { days }\end{array}$ \\
\hline & Lambs & & $\begin{array}{l}15 \mathrm{~g} / \text { tonne of feed can be fed the } \\
\text { ewes for } 4 \text { wks before lambing until } \\
\text { weaning and to lambs from 4-20 } \\
\text { wks of age }\end{array}$ \\
\hline \multirow[b]{2}{*}{ Lasolacid } & Cattle & & $\begin{array}{l}1 \mathrm{mg} / \mathrm{kg} / \text { day to a maximum of } \\
360 \mathrm{mg} / \mathrm{head} / \text { day }\end{array}$ \\
\hline & Lamb & & $\begin{array}{l}\text { 25-100mg/kg feed from weaning } \\
\text { until market. Also in ewes diet } 2 \\
\text { Also in ewes diet } 2 \text { weeks before } \\
\text { and until } 60 \text { days of lambing } \\
\text { A combination of monensin and } \\
\text { lasolacid at } 22 \text { and } 100 \mathrm{mg} / \mathrm{kg} \text { of } \\
\text { diet respectively, is an effective } \\
\text { prophylactic against naturally } \\
\text { occurring coccidiosis under feedlot } \\
\text { conditions. }\end{array}$ \\
\hline \multirow[t]{2}{*}{ Toltazuril } & Lamb & \multirow{2}{*}{$\begin{array}{l}20 \mathrm{mg} / \mathrm{kg} \text { as a single treatment can } \\
\text { significantly reduce oocyst output } \\
\text { in naturally infected labs for } 3 \text { wks }\end{array}$} & $\begin{array}{c}20 \mathrm{mg} / \mathrm{kg} \text { as a single treatment } \\
10 \text { days after being turned out to } \\
\text { pasture will prevent coccidiosis } \\
\text { which occur normally without } \\
\text { medication }\end{array}$ \\
\hline & Piglets & & $\begin{array}{l}\text { A single oral dose of } 1.0 \mathrm{ml} \text { of } \\
\text { toltrazuril given to piglets } 3-6 \text { days } \\
\text { old reduced the occurrence of } \\
\text { coccidiosis }\end{array}$ \\
\hline
\end{tabular}




\begin{tabular}{|l|r|c|c|}
\hline \multirow{2}{*}{ Decoquinate } & \multirow{2}{*}{ Calves } & $\begin{array}{c}0.5 \mathrm{mg} / \mathrm{kg} \text { BW from } 9 \text { weeks to } 24 \\
\text { weeks of age }\end{array}$ \\
\cline { 2 - 2 } & Goats & $0.5 \mathrm{mg} / \mathrm{kg} \mathrm{BW}$ is effective \\
\cline { 2 - 3 }
\end{tabular}

\section{g. Conclusions on gastrointestinal parasites of Chickens}

The majority of work on helminths in chicken was obtained from Africa, Asia and North America with limited published work done in the Caribbean. Due to the long pre-patent period of helminths they are usually found in free-ranging chickens and layers. Eimeria spp. causes major economic damage to the poultry industry due to the deleterious effects on the birds' digestive tract.

\section{Treatment and Control of Gastrointestinal parasites}

\section{a. Management practices and drugs strategies}

In Brazil animals were reared in organic operations and traditional dairy cattle farms to compare animal performance and health. Organic farms had lower milk production per animal, lower calf mortality, less incidences of mastitis, few rates of spontaneous abortions and reducted ecto-parasitic load. However organic farms had a greater prevalence of internal parasites compared to the conventional farm Sliva et al. [18]. Farmers in Kenya perceived the use of anthelmintics in drought times had no impact on the productivity of small ruminants but states that the rainy season was the reason for increased performance. The farmers didn't consider endoparaistes as having an effect on the animals unless clinical signs were seen Okell et al. [19].

Anindo et al. [20] used Medicated molasses urea block with fenbendazole in sheep production and recorded an increase in feed intake and decrease in faecal eggs count. Arece-Garcia et al. [21] studied ewes using two management procedures for control of parasites. One group selective use of anthelmintic was done. Only animals with clinical signs of parasites were treated whilst the alternative treatment used conventional deworming system. The results showed that there was no significant difference between the two treatments with respect to animal performance. The strategic strategy was then recommended as it reduced the amount of therapeutic drugs being used which reduces anthelmintic resistance Arece-Garcia [21]. Dried banana leaves were fed to sheep artificially infected with Haemonchus and decreased faecal egg hatchability was seen due to the tannins present in the leaves Gregorya et al. [22].

Medicated fenbendazole urea block had caused an increase in weight gain in goats as compared to the negative control group which wasn't treated with fenbendazole Abid et al. [23]. Cassava foliage fed to goats had increased growth rates and reduced parasite infestation. This was due to the high levels of tannins in the leaves of the cassava plant Sokera and Preston [24]. Phengvichith and Preston [25] also did an experiment in supplementing goats with cassava foliage and found similar result to Sokera and Preston [24]. There was an increase in live-weight gain and reduction in faecal egg count as compared to a negative control group. In Bishoftu
Town a survey was done with sheep reared in urban and peri-urban environment. The most common athelmintic used was albendazole followed by ivermectin and levamisole.

The reasons for the use of anhelmintics were general disease symptoms (45.8\%) such as emaciation, rough coat, weakness. $23 \%$ of farmers treated due to digestive disturbances, $18.3 \%$ gave anthelmintics for simple deworming and finally $10 \%$ used anthelmintics for respiratory conditions Datiko et al. [26]. Mahieu and Aumont [27] investigated the use of sheep and cattle in alternating grazing systems. Lambs were grown in the alternate system (Cattle and Sheep) and the control (Sheep only) and the 70 day old lamb weight in the alterative system was higher than the control. There was also no significant difference in the faecal egg count in sheep reared under the two conditions.

\section{b. Anthelmintic Resistance in Domestic Animals}

Cheng et al. [16] investigated the efficacy of Piperazine citrate, Levamisole hydrochloride and Albendazole in chickens. Levamisole $(25 \mathrm{mg} / \mathrm{kg})$ was effective against caecal worms Heterakis spp., $\mathrm{H}$. isolonche and Sublura brumpti but was ineffective to tapeworms and Tertameres americana. Albendazole $(20 \mathrm{mg} / \mathrm{kg})$ was effective against Heterakis spp., Sublurua brumpti, Tetrameres americana, Railletina tetrogena and $R$. echinobothrida. Piperazine citrate $(3 \mathrm{mg} / \mathrm{kg})$ was only effective against Ascaridia galli and ineffective against nematodes and trematodes. In Bangladesh Trichostrongylus spp., Oesophagustomum spp. and Strongyloides spp. were resistant to Albendazole using the Faecal egg count reduction test (FERT). This was due to the over use of the drug by farmers. Anthelmintic resistance can be small in farm holders that use anthelmintics for clinical disease Hogue et al. [28]. In Mexico, anthelmintic resistance of parasites in Beef cattle was examined. Faecal egg reduction and inhibition of egg hatchability was used for albendazole, ivermectin and levamisole. The results showed resistance to ivermectin $(32 \%$ reduction faecal egg reduction).

Albendazole and levamisole were effective (95\% and 100\% reduction in faecal egg reduction) Muniz-Lagunez et al. [29]. In South Africa small scale farmers were investigated for the presence of anthelmintic resistance of albendazole, levamisole and ivermectin. All anthelmitic in the study as ineffective in reduction of faecal egg count in the animals with only a couple (2) farms have susceptibility to the drugs Tsotesti et al. [30]. Algeria -Lopez [31] investigated the efficacy of ivermectin against ecto and endo parasites of cattle. The results showed that gastrointestinal parasites were resistant to ivermectin but the tick Rhicephalus were susceptible to the drug. In Ethopia the relationship of dose and efficacy of albendazole was investigated. In goats $3.8 \mathrm{mg} / \mathrm{kg}$, $5.7 \mathrm{mg} / \mathrm{kg}$ and $7.6 \mathrm{mg} / \mathrm{kg}$ was given and all dosages was ineffective (65.5\%, 81.4\% and $84.1 \%)$ and showed the helminths developed 
resistance to the drugs Euale et al. [32]. In Trinidad the efficacy of anthelmintics were investigated in sheep. Faecal egg reduction tests were carried out and the results showed heliminth were resistant to albendazole (46-62\% reduction) fenbendazole (44$61 \%$ reduction) and levamisole (53-81\%). Ivermectin was effective in decreasing the eggs count (95-97\% reduction) George et al. [33].

\section{c. Alternatives and Herbal Remedies in the control of}

\section{Parasites}

Lone et al. [34] investigated the use of Euphorbia helicoscopia as an anthelmintic to control Haemonchus contortus. Faecal Egg Count Reduction (FECRT), egg hatchablity and larval development inhibition was used. It reduced faecal egg count in 18 days post treatment. Adult motility showed the highest of $98 \%$ efficacy at $5 \mathrm{mg} / \mathrm{kg}$. When compared with levamisole the plant extract had low effects on egg hatchability. A collection of condensed tannins from Balanites aegyptiaca, Tamarindies indica and Celtis toka were evaluated for anthelmintic treatment. C. toka had the fastest adult worm mortality and was as high as ivermectin whilst the other two forages had no significant effect. There was no significant difference in egg hatchability between ivermectin, T. indica and B. aegytiaca. The three plant extracts (Balanites aegyptiaca, Tamarindies indica and Celtis toka) was observed to inhibit larval development by $100 \%$ which was similar to ivermectin Assefa et al. [35].

Leucaena leucocephala and Salix bablyonica was investigated as anthelmintic against Haemonchus spp., Ostertagia spp., Oesophogostomum spp., Cooperia spp., Bunustomum spp., N. battus, Chabertia spp., Strongyloides papulosus and Nematodirus spathiger. There was a reduction in the egg count for Strongyloides spp., S. papulosus, D. filarial, M. capillaris and Eimeria spp. The extract had no effect on egg reduction on Trichuris spp., Nematodirus spp. and Fasciola spp. Hernandez et al. [36]. Feitosa et al. [37] used of pumpkin seed for its anthelmintic properties in ostriches. In the study the pumpkin seeds fed at $1 \mathrm{~g} / \mathrm{kg}$ body weight gave a $90 \%$ reduction in faecal egg count. The control and albendazole showed no reduction in the faecal egg count. Extracts of Larrea tridentata was used as an anthelmintic against Haemonchus contortus larvae. Concentration of 12.5 to $50 \mathrm{mg} / \mathrm{ml}$ leads to low mortality of sheathed and ex-sheathed larvae. When compared to Ivermectin, Larrea tridentata had 70\% efficacy with Ivermectin having 99\% efficacy against larvae Garcia et al. [38].

Consensed tannins of Sesbania sesban and Desmodium intortum was investigated as an alternative anthelmintic for Haemonchus contortus in goats. It was found that levels of the 1mg/ $\mathrm{ml}$ tannin from $D$. intortum significantly inhibited larval migration but $S$. sesban was ineffective. Goats given $D$. intortum extract showed no difference in weight compared to the negative control which was attributed the incomplete removal of parasites by the tannins Debale et al. [39]. Biological control was also investigated as an alternative control for helminths in Sweden where Diddingtonia flagrans a fungus was fed to sheep which trap anthelmintic larvae. The experiment showed that there was no difference in the performance of the lambs that received treatment and the negative control group.

In the experiment the finding were attributed to the high initial level of nutrition for both groups Waller et al. [40]. Gastrointestinal parasitism in Creole goats was investigated using mixed breed grazing systems in post-weaning period (3-7 months). Four groups were grazed with different stocking rates bases on live-weight; 25\% (kids $150 \mathrm{~kg}$ LW0.75 and cattle $450 \mathrm{~kg}$ LW0.75), 50\% kids (Kids $300 \mathrm{~kg}$ LW0.75 and cattle $300 \mathrm{~kg}$ LW0.75), 75\% (kids 450 kg LW0.75 and cattle $150 \mathrm{~kg}$ LW0.75) and 100\% kids (kids less than $600 \mathrm{~kg}$ LW0.75). There animals were then exposed to pasture contaminated with parasites for 3-7 months. Faecal egg count was significantly higher for groups having $100 \%$ and $75 \%$ goats.

The kids were then infected with $H$. contours at 11 months of age. In contrast to the faceal egg counts seen earlier faecal egg counts for the second infection (experimental) were lower for the goats which were reared at $100 \%$ and $75 \%$ kids respectively. It suggested that the animals had a degree of resistance based on their first exposure to the parasites at pasture Cei et al. [41]. Cei et al. [42] investigated the effect of growing kids in different housing environments. The results of the study showed that rearing animals gave better growth than animals in collective pens. Both groups were exposed to 10000 L3 larvae of Haemonchus contortus and the results showed that the individual reared animals performed better than the collectively reared goats. This shows with proper housing and management some of the effects of parasitism can be avoided.

\section{d. Conclusions on the treatment and control of} gastrointestinal parasites

It has been reported that a wide variety of drugs can be used to treat anthelmintics and coccidia which are present in Old World Domesticated animals. With increases in the improper use and frequency of these drugs, helminths and coccida have developed some resistance. Now farmers and scientist are searching for alternative extracts (drugs) and management technique to control gastrointestinal parasitism in these animals.

\section{Summary of Conclusions}

a) The writings of Lapage [5], Krull [4] and Soulsby [3] have been found to be in agreement with each other on what is a parasite. In summary, a parasite is an organism that lives in its host, is metabolically depend on the host for its survival and negatively affecting the host's health and performance either clinically or sub-clinically.

b) The literature has also suggested that animal associations can be broken down into four relationships (1) parasitism, (2) commensalism, (3) symbiosis and (4) mutualism.

c) Parasites present in the digestive system of the horse caused a wide variety of clinical signs which included diarrhoea, anemia, melena, peri-arnal irritation.

d) Small strongyles were extremely pathogenic to horses 
and caused damage to digestive and circulatory system. The migration of these parasites caused damage to several organs before returning to its predilection site.

e) Parasites of the pigs which were found in the digestive tracks caused economic losses in the following ways; (1) larval migration causing of damaged organs and condemning of affected organ at the abattoir, (2) decrease growth rate of infected pigs (3) death of animals that succumb to parasitic disease.

f) Strongyloides spp. has two states, a parasitic and nonparasitic state with the females being parasitic and were found in the final host.

g) Adult cestodes were absent in the digestive tract of pigs.

h) Haemonchus spp., Ostertagia spp. and Trichostrongylus spp. caused severe damage to the abomasum of Old World Domestic Ruminant and impeded ruminant production.

i) Nematodirus spp. affected sheep causing devastating clinical signs whereas when these parasites are found in other ruminants caused milder clinical signs.

j) Subcutaneous oedema (Bottle Jaw) were reported in ruminants when large numbers of gastrointestinal parasites was present which removed protein (blood, plasma protein).

k) The majority of work on helminths in chicken was obtained from Africa, Asia and North America with limited published work done in the Caribbean.

l) Due to the long pre-patent period of helminths they are usually found in free-ranging chickens and layers.

m) Eimeria spp. causes major economic damage to the poultry industry due to the deleterious effects on the birds' digestive tract.

n) It has been reported that a wide variety of drugs can be used to treat anthelmintics and coccidia which are present in Old World Domesticated animals.

o) With increases in the improper use and frequency of these drugs, helminths and coccida have developed some resistance.

p) Further research on alternative extracts (drugs) and management technique to control gastrointestinal parasitism in these animals.

\section{References}

1. Reitz EJ (1992) The Spanish Colonial Experience and Domestic Animals. Historical Archaeology 26 (1): 84-91.

2. Xande A (1999) Animal and quality of life in traditional society in the Caribbean islands. Livestock Production Science 59: 137-143.

3. Soulsby EJL (1982) Helminths, arthropods and protozoa of domesticated animals ( $7^{\text {th }}$ Edn): London: Baillière Tindall. pp. 329.
4. Krull WH (1968) Notes in Parasitology. University Press of Kansas, Manhattan p. 83-100.

5. Lapage G (1954) Veterinary Parasitology. Oliver and Boyd. Edingburg; London p. 12-19.

6. MSDAVET (1985) Parasites of Horses $2^{\text {nd }}$ Edition. Merck \& Co. Inc., Rahaway, New Jersey, USA p. 27-34.

7. Dua K (2012) Infectious Diseases of Farm Animals. Alpha Science Internation Ltd. Oxford, UK p. 515-535.

8. Zajac AM, Conboy GA (2017) Veterinary clinical parasitology. John Wiley \& Sons pp. 94-174.

9. Belschner HG (1967) Cattle Diseases. Angus and Robertson Ltd. pp. 12162.

10. Hendrix C, Robinson E (2017) Diagnostic Parasitology for Veterinary Technicians ( $6^{\text {th }}$ edn.), Elsiever p. 56-80.

11. Haberman JJ (1953) The Farmer's Veterinary Handbook. Prentice-Hall Inc. New York, USA p. 54.

12. Parker WH (1976) Health and Disease in Farm Animals (2nd Edition). Pergamon Press, USA pp.260.

13. Makuratirwa S, Hove T, Esmann EB, Hoj CJ, Permin A, et al. (2001) A survey of parasitic nematodes infection in chickens in Rural Zimbabwe. Ondersterpoort Journal of Veterinary Research 68(3): 183-186.

14. Mungube EO, Bauri SM, Nzioka SM, Tenhagen BA, Wamae LW, et al. (2008) Prevalence of parasitism of local scavenging chickens in selected semi-arid zone of Eastern Kenya. Tropical Animal Health and Production 40(2): 101-109.

15. Maina AN, Waruir RM, Mbuthia PG, Munyua WK, Otieno RO, et al. (2017) Prevalence of gastrointestinal parasites in indigenous chickens slaughtered at live bird market in Nairobi county Kenya. Livestock Research For Rural Development 29(12).

16. Cheg HW, Kemboi DC, Bebora LC, Maingi N, Mbuthia PG, et al. (2015) Studies on seasonal prevalence of ecto- and endo- parasites in indigenous chickens of Mbeere subcounty, Kenya.Livestock Research for Rural Development 27(6).

17. Chota A, Sikasunge CS, Phiri AM, Musukua MN, Haazle F, et al. (2010) A comparative study on the efficacy of Piperazine and Carica papaya for the control of helminths parasites in village chickens of Zambia. Tropical Animal Health and Production 42(3): 315-318.

18. Silva JB, Faguntes GM, Soares JPG, Fonseca AH, Muir JP (2014) A comparative study of the production performance and animal health practices in organic and conventional dairy systems. Tropical Animal Health and Production 46(7): 1287-1295.

19. Okell CN, Mariner J, Allport R, Buono N, Muternbi HM, et al. (2016) Anthelmintic administration to small ruminants in emergency drought responses: Assessing the impact of two locations in Northern Kenya. Tropical Animal Health and Production 48(3): 493-500.

20. Anindo D, Toe F, Tembely S, Mukasa-Mugerwa E, Lahlou-Kassi A, et al. (1998) Effect of molasses-urea-block (MUB) on dry matter intake, growth, reproductive performance and control of gastrointestinal nematode infection of grazing Menz ram lambs. Small Ruminant Research 27(1): 63-71.

21. Arece Garcia J, Lopez Levya Y, Gonzales Garduno R, Torres Hernandez G, Rojo Rubio R, et al. (2016) Effect of selective anthelmintic treatments on health and production parameters in Pelibuey ewes during lactation. Tropical Animal Health and Production 48(2): 283-287.

22. Gregorya L, Yoshiharab E, Silva LKM, Marquesa EC, Ribeiroa BLM, et al. (2017) Anthelmintic effects of dried ground banana plant leaves (Musa spp.) Fed to sheep artificially infected with Haemonchus contortus 
and Trichostrongylus columbriformis. African Journal of Traditional Complemententary and Alternative Medicine 14 (1): 138-144.

23. Abid R, Khan I, Bhatti JA, Shah Z, Zahoor A, et al. (2016) Effect of medicated urea molasses blocks on sub-clinical parasitic infestations in goats. Online Journal of Animal and Feed Research 6(2): 57-61.

24. Sokerya S, Preston TR (2003) Effect of grass or cassava foliage on growth and nematode parasite infestation in goats fed low or high protein diets in confinement. Livestock Research for Rural Development 15(8).

25. Phengvichith V, Preston TR (2011) Effect of feeding processed cassava foliage on growth performance and nematode parasite infestation of local goats in Laos. Livestock Research for Rural Development 23(1).

26. Datiko J, Terefe G, Bekele J (2013) Anthelmintic utilization practices and prevalence of gastrointestinal helminth infections in sheep kept in the urban and peri-urban areas of Bishoftu Town. Tropical Animal Health and production 45(2): 633-639.

27. Mahieu M, Aumont G (2009) Effect of cheep and cattle alternate grazing on sheep parasitism and production. Tropical Animal Health and Production 41(2): 229-239.

28. Hogue MN, Bigium N, Nooruddin M (2003) Albendazole resistance in gastrointestinal nematode parasites of Cattle in Bangladesh. Tropical Animal Health and Production 35(3): 219-222.

29. Muniz-Lagunes A, Gonzalez-Garduno R, Lopez-Arellano ME, RamiresValverde R, Ruiz-Flores A, et al. (2015) Anthelmintic resistance in gastrointestinal nematodes from grazing beed cattle in Campeche State, Mexico. Tropical Animal Health and Production 47(6): 1049-1054.

30. Tsotesti AM, Njiro S, Katsande TC, Moyo G, Baloyi F, et al. (2013) Prevalence of gastrointestinal helmintic resistance on small-scale farms in Gauteng Provine, South Africa, Tropical Animal Health and Production 45: 751-761.

31. Algeria-Lopez MA, Rodriguez-Vivas RI, Torres-Acosta FJ, Ojeda-Chi MM, Rosado-Aguilar JA (2015) Use of Ivermectin as Endoparasite in Tropical Cattle herds Generates Resistance in Gastrointestinal Nematodes and the Tick Rhipichalus micropus (Acari: Ixodidae). Journal of Medical Entomology Advances 52(2): 214-221.

32. Euale T, Chaka H, Gizaw D (2009) Efficacy of Albendazole against nematode parasites isolated from a goat farm in Euthopia: relationship between dose and efficacy in goats. Tropical Animal Health and Production 41(7): 1267-1273.

33. George N, Persad K, Sagam R, Offiah VN, Adesiyun AA, et al. (2011) Efficacy of commonly used anhelmintics: First report of multiple drug resistance in gastrointestinal nematode of sheep in Trinidad. Veterinary Parasitology 183(1-2): 194-197.

34. Lone BA, Bandh SA, Christi MZ, Bhat FA, Tak H, et al. (2013) Anthelmintic and antimicrobial activity of methanolic and aqueous extracts of Euphora helioscopia L. Tropical Animal Health and Production 45(3): 743-749.

35. Assefa A, Kechero Y, Tolemariam T. Kebede A, Shumi E (2018) Anthelmintic effect of multipurpose fodder trees extract against Haemonchs contortus. Tropical Animal Health and Production 50(4): 727-732.

36. Hernandez PM, Saleem AZM, Elghardour, MMMY, Cipriano- Salazar M, et al. (2014) Anthelminthic effect of Salix babylonica L. and Leucaena leucocephala extract in growing lambs. Tropical Animal Health and Production 46(1): 173-178.

37. Feitosa TF, Vilela VLR, Athayde RCR, Braga FR, Dantas ES, et al. (2013) Anthelmintic efficacy of pumpkin seed (Cucurbita pepo Linneus 1753) on ostrich gastrointestinal nematodes in a semi-arid region of Paraiba State, Brazil. Tropical Animal Health and Production 45(1): 123-127.

38. Garica JE, Gomez L, Mendoza-de-Gives P, Rivera-Corona J, Millan-Orozco J, et al. (2018) Anthelmintic activity of hydro-methanolic extracts of Larrea tridentata against larvae of Haemonchus contortus. Tropical Animal Health and Production p: 1-7.

39. Debala E, Tolera A, Eik LO (2012) Condensed tannins for Sesbania sesban and Desmodium intorum as a means of Haemonchus contortus control in goats. Tropical Animal Health and Production 44(8):1939-1944.

40. Waller PJ, Ljungstrom BL, Schwan O, Rudby Martin L, Morrion DA, et al. (2006) Biological Control of Sheep Parasites using Duddingtonia flagrans: Trials on Commercial Farms in Sweden. Acta vet. scand. 47: 23-32.

41. Cei W, Mahieu M, Philibert L, Arquet R, Alexandre G, et al. (2015) Impact of the post-weaning parasitism history on an experimental Haemonchus contortus infection in Creole goats. Veterinary Parasitology 207(1-2): 165-169.

42. Cei W Banbou JC, Silou F, Mounoussamy F, Alexandre G (2014) Growth and carcass traits of Creole kids experimentally infected with Haemonchus contortus: effects of sex, housing conditions and slaughter weights. Livestoock Research for Rural Development 26(11).

43. Taylor DJ (1986) Pig Diseases. The Bulgarian Press (Cambridge) Ltd. Foxton, Cambridge, USA pp.176.

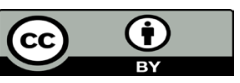

This work is licensed under Creative Commons Attribution 4.0 License

Submission Link: Submit Article

DOI: $10.32474 / C D V S .2018 .01 .000110$

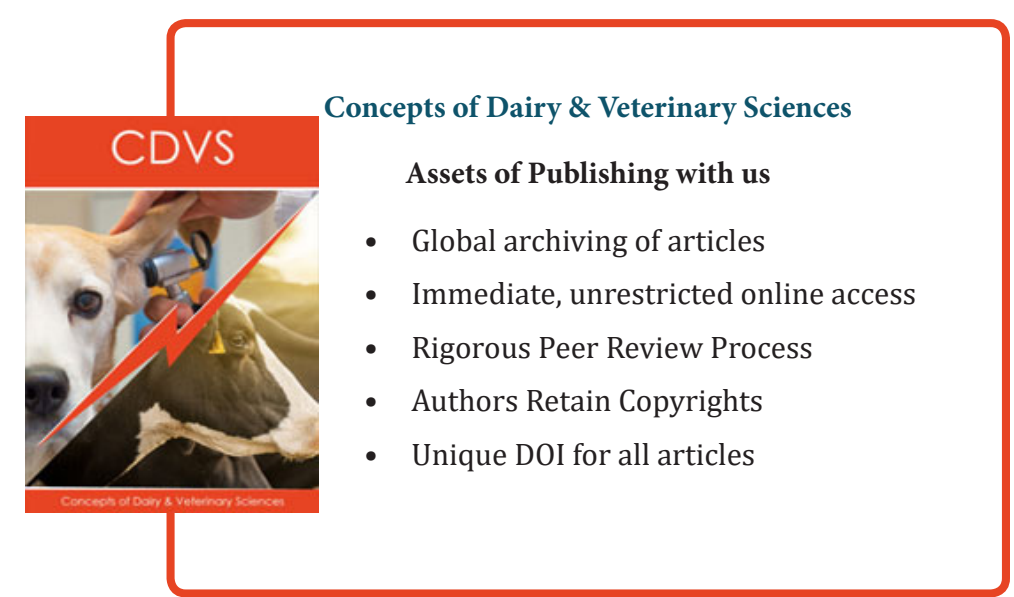

